\title{
ESTIMATING TRASH CONTENTS BY USING HVI INSTRUMENT FOR SOME EGYPTIAN COTTON CULTIVARS
}

(Received: 20.10.2014)

\author{
By \\ O. D. M. Nour \\ Cotton Research Institute, Agricultural Research Center, Giza, Egypt
}

\begin{abstract}
There is an increasing demand for fast and reliable method to estimate trash in cotton bale. One of the most important factors is the feasibility of the use of $\mathrm{Rd} \%$ and ${ }^{+} \mathrm{b}$ or both in cotton. Country cotton production data were used to determine $\mathrm{Rd} \%$ and ${ }^{+} \mathrm{b}$. The objective of this study was to determine the availability of cotton gin trash in the three cotton cultivars, i.e. Giza 9o " (upper Egypt). Giza 86 and Giza 88 ( Delta cottons). Differences in color measurements Rd\% and ${ }^{+} \mathrm{b}$ of seven lint grades.ie. Good+1/4, Good, Good-1/4, Fully good, fair/Good, Fully good fair, Good fair/ Fully good fair and Good fair, were used.

The results indicated that the three cottons under study Giza 90., Giza 86 and Giza 88 showed significant differences in total trash by using $\mathrm{Rd} \%$ or $\mathrm{b}^{+}$and both of them. Lint grades showed significant differences too. Giza 86 and Giza 88 (Delta cottons)had lower trash compared to upper Egypt cotton, Giza 90.

High lint grades " Good $+1 / 4$ " showed lower trash of all varieties, while Good fair (GF) grade showed highest trash.
\end{abstract}

Key words: cotton, fiber, colorRd, grade, Trash.

\section{INTRODUCTION}

Cotton gin trash is a byproduct of the cotton ginning process and consists of the dried burr of the cotton boll stems, leaf fragments and some short or damaged cotton fibers. The present study was carried out to identify the trash contents variation of cotton grade if composite rating is determined by color. The amount of trash in the sample is due to different lint grades. Hegab (1978) reported that the percentage of non-lint content gradually increased as the cotton grade decreased. Also, Khaled (2001) found that the differences in total trash between cotton grades were considerabley higher than the differences between varieties. The higher cotton grades showed lower total trash content than the lower ones. Abdel - Mohsen and Ahmed (1973) demonstrated that trash content had a bad effect on cotton processing and manufacturing in the conventional spinning. It increased the card waste, the comb waste and the ends down which affected the spinning efficiency. Abdel -Mohsen and Al- Ashwat (1976) found that the effect of reflectance of light by lint and non lint content grade were highly significant. Reflectance was positively correlated with the grade, while non- lint content was negatively correlated with it . The present work was carried out to investigate:

1.Differences in trash content, for three cotton varieties with seven lint grades and their interactions.

2.Determine $\mathrm{Rd} \%$ and ${ }^{+} \mathrm{b}$ by using HVI 900ASTM D4604(2005). "Test Methods for Measurements of cotton fibers by high volume instruments (HVI) Motion control fiber information system.

3. Contribution and prediction equation for some Egyptian commercial cotton varieties: Giza 90, Giza 86 and Giza 88.

\section{MATERIALS AND METHODS}

Seven lint cotton grades were chosen to represent each of the chosen three varieties. Designation of the chosen grades were similar in all varieties being; Good $+1 / 4$, Good, Good$1 / 4$, fully Good fair / Good., fully Good fair.,Good fair/ Fully Good fair, and Good fair.

\subsection{Studied Characters}

\subsubsection{Lint grade}

The line cotton of each sample was determined after ginning for statistical purposes. The grades were converted to an index (Sallouma, 1970) as 
shown in the following tabulation.

\subsubsection{Trach content}

The micro dust, trash and fiber fragments were determined on the micro dust and trash analyzer ( MDTA3) ( ASTM 2012)

$\begin{array}{ccc}\text { Grade } & \text { abbreviation } & \text { Index } \\ \text { Fully Good } & \text { FG } & \mathbf{4 8} \\ \text { Good } & \text { G } & \mathbf{4 0} \\ \text { Fully Good Fair } & \text { FGF } & \mathbf{3 2} \\ \text { Good Fair } & \text { GF } & \mathbf{2 4} \\ \text { Fully Fair } & \text { FF } & \mathbf{1 6} \\ \text { Fair } & \text { F } & \mathbf{8}\end{array}$

According to the above index, the grade of each of the seven chosen grades was calculated as follows:

$\begin{array}{cc}\text { Grade } & \text { abbreviation } \\ \text { Good+1/4 } & \text { G+1/4 } \\ \text { Good } & \text { G } \\ \text { Good-1/4 } & \text { G-1/4 } \\ \text { Fully Good Fair/Good } & \text { FG/G } \\ \text { Fully Good Fair } & \text { FGF } \\ \text { Good Fair/Fully Good Fair } & \text { GF/FGF } \\ \text { Good Fair } & \text { GF }\end{array}$

\subsection{Experimental design and statistical analysis:}

2.2.1. Completely randomized design with three replicates was used to carry out the analysis of variance in lint color measurements " $\mathrm{Rd} \%$ $\&^{+} b$ "and total trash content due to cotton varieties and lint grades. Data were statistically analyzed according to the procedures of Sendecor and Cochrar (1981). The least significant differences ( L.S.D) test at 5\% level of significance are used to compare treatment means.

2.2.2. The regression analysis was used to study the relative importance of color measurements " Rd\% \& ${ }^{+} \mathrm{b}$ " for some Egyptian cotton varieties. Representative samples of lint grade in all varieties were drawn to record the color measurements " $\mathrm{Rd} \% \&^{+} \mathrm{b}$ " and total trash at the Cotton Research Institute, Agric. Res. Center., under controlled atmospheric condition of $21{ }^{\circ} \mathrm{C} \pm 2$ temperature and $65 \% \pm 2$ relative humidity.

\section{RESULTS AND DISCUSSION}

The color of cotton lint is one of the most important factors in determining cotton grade. The results and discussion of this investigation were presented in the following main parts:
3.1. Differences in lint color measurements $\mathrm{Rd} \%$ " reflectance degree ${ }^{+} b$ yellowness and total trash for some Egyptian cotton varieties.

3.2. The relative importance of color measurements "Rd\% $\quad \&^{+} b "$ with some cotton varieties.

The results in Table (1) showed the differences in color measurements $\left(\mathrm{Rd} \% \&^{+} \mathrm{b}\right)$ and the total trash from one variety to another. The statistical analysis showed significant differences between color measurements" Rd\% reflectance degree $\%, "{ }^{+} b "$ (yellowness) and the total trash for the same cotton varieties.

Table (1): Contribution of color measurements "Rd\%, $b^{+"}$ and the total trash for some Egyptian cotton varieties

\begin{tabular}{|c|c|c|c|}
\hline Cultivars & $\mathbf{R d \%}^{\text {M }}$ & ${ }^{\mathbf{b}}$ & TT \\
\hline Giza 90 & 63.11 & 12.11 & 9.44 \\
\hline Giza 86 & 71.79 & 8.88 & 7.18 \\
\hline Giza 88 & 63.65 & 12.92 & 7.03 \\
\hline L.S.D ( 0.05) & 0.42 & 0.11 & 0.19 \\
\hline
\end{tabular}

The results in Table (1) indicated that Giza 90 and Giza 88 contained lower " Rd\%" than Giza 86. Also, "+ b" results showed that Giza 90 and Giza 88 gave the highest ${ }^{+} b$ readings compared to Giza 86. This trend could be due to Giza 86 being white cotton color, but Giza 90 or Giza 88 recorded creamy cotton color. While ,Giza 90 contained higher total trash $9.44 \%$ due to Upper Egypt tough weather. Giza 86 and Giza 88 contained lower total trash" 7.18 and 7.03" respectively". The differences between the three Egyptian cotton under study were of low magnitude despite of its statistical significance.

Data in Table (2) indicated that the differences between lint grades of the varieties in reflectance $(\mathrm{Rd} \%)$ were very high in different lint grades of Giza 86 than different lint grades of Giza 90 or Giza 88. GF lint grades showed the least means of these parameters, while, G lint grades showed the highest means. The $\mathrm{Rd} \%$ ranged in Giza 90 from $57.8 \%$ in GF lint grade to 68.5 or $68.6 \%$ in $\mathrm{G}+1 / 4$ or $\mathrm{G}$ lint grades. Also, Giza 88 ranged from $61.0 \%$ in GF to $66.5 \%$ or $65.6 \%$ in $\mathrm{G}+1 / 4$ or $\mathrm{G}$ lint grades. This is because Giza 90 and Giza 88 are creamy cotton color while, Giza 86 more white and bright. So, it ranged from $67.2 \%$ in G F to 78.1 in $\mathrm{G}$ lint grade. The same results were recorded in yellowness $\left({ }^{+} \mathrm{b} \%\right)$, (Table 3$)$. The lint grade of the three varieties under study" Giza 90 ". 
Table(2):Lint color measurement "Rd\%" for the different lint grades for some cotton varieties

\begin{tabular}{|c|c|c|c|c|}
\hline \multirow{2}{*}{$\begin{array}{c}\text { Cotton } \\
\text { grade (g) }\end{array}$} & \multicolumn{3}{|c|}{ Cotton varieties } & \multirow{2}{*}{ Meain } \\
\cline { 2 - 4 } G.90 & G.86 & G.88 & \\
\hline G+1/4 & 68.5 & 77.0 & 66.5 & 70.7 \\
\hline G & 68.6 & 78.1 & 66.6 & 71.1 \\
\hline G-1/4 & 65.1 & 76.7 & 64.8 & 68.9 \\
\hline FGF/G & 62.1 & 67.4 & 63.1 & 64.2 \\
\hline FGF & 61.4 & 67.8 & 62.0 & 63.7 \\
\hline GF/ FGF & 58.4 & 68.4 & 61.7 & 62.8 \\
\hline GF & 57.8 & 67.2 & 61.0 & 62.1 \\
\hline Mean & 63.1 & 71.8 & 63.7 & \\
\hline $\begin{array}{c}\text { L.S.D 5\% } \\
\text { VxG }\end{array}$ & \multicolumn{3}{|c}{0.64} & \\
\hline
\end{tabular}

Giza 86 and Giza 88" assured that all lint grades of Giza 86 ranged least than lint grades of Giza90 and Giza 88. As shown in Table (3) the cottons showed significant differences in ${ }^{+} b$ means, where the recorded means were 12.1, 8.89 and 12.90 for Giza90, Giza 86 and Giza 88. These results indicated that Giza 86 is more white bright and low yellowness as compared to Giza 90 and Giza 88.

These results are in line with those obtained

Table (4): Total trash potential for the different lint grades for some cotton varieties

\begin{tabular}{|c|c|c|c|c|}
\hline \multirow{2}{*}{$\begin{array}{c}\text { Cotton } \\
\text { Grade (g) }\end{array}$} & \multicolumn{3}{|c|}{ Cotton varieties } & \multirow{2}{*}{ Mean } \\
\cline { 2 - 4 } & G. 90 & G.86 & G.88 & \\
\hline G+1/4 & 5.36 & 4.68 & 3.54 & 4.53 \\
\hline G & 6.80 & 5.04 & 4.46 & 5.43 \\
\hline G-1/4 & 7.69 & 6.20 & 5.63 & 6.51 \\
\hline FGF/G & 9.28 & 6.69 & 7.12 & 7.70 \\
\hline FGF & 10.87 & 7.30 & 8.72 & 8.96 \\
\hline GF/FGF & 12.40 & 9.22 & 9.52 & 10.38 \\
\hline GF & 13.68 & 10.79 & 10.20 & 11.56 \\
\hline Mean & 9.44 & 7.13 & 7.03 & \\
\hline $\begin{array}{c}\text { L.S.D 5\% } \\
\text { VxG }\end{array}$ & \multicolumn{3}{|c|}{0.29} & \\
\hline
\end{tabular}

by Abdel-Moshen and Al-Ashwat (1976), Barker and Lyons (1977), Galyon and Shofner (1992), Anthony (1993) and El- Shafei (1995).

Data in Table (4) indicated that trash content is considered one of the most important factors that determine lint grade, therefor it increases as the lint grade goes down and decreases in the high lint grades. The differences between lint grades of the varieties under study were significant. The recorded means of the total trash were $9.44 \%, 7.13 \%$ and $7.03 \%$ for Giza 90, Giza 86 and Giza 88 cotton varieties, respectively. $G+1 / 4$ lint grades showed the lowest means of those parameters., while GF grades showed the highest ones.
Table(3): Lint color measurement" "b"for the different lint grades for some cotton varieties

\begin{tabular}{|c|c|c|c|c|}
\hline \multirow{2}{*}{$\begin{array}{c}\text { Cotton } \\
\text { Grade (g) }\end{array}$} & \multicolumn{3}{|c|}{ Cotton varieties } & \multirow{2}{*}{ Mean } \\
\cline { 2 - 4 } G+1/4 & 12.00 & 8.6 & 12.5 & 11.00 \\
\hline G & 12.3 & 8.4 & 12.5 & 11.1 \\
\hline G-1/4 & 11.6 & 8.5 & 13.0 & 11.00 \\
\hline FGF/G & 12.1 & 8.8 & 12.9 & 11.3 \\
\hline FGF & 12.1 & 9.5 & 13.0 & 11.5 \\
\hline GF/FGF & 12.7 & 9.0 & 13.2 & 11.6 \\
\hline GF & $\mathbf{1 1 . 9}$ & $\mathbf{9 . 5}$ & $\mathbf{1 3 . 4}$ & $\mathbf{1 1 . 6}$ \\
\hline Mean & $\mathbf{1 2 . 1}$ & $\mathbf{8 . 9}$ & $\mathbf{1 2 . 9}$ & \\
\hline $\begin{array}{c}\text { L.S.D 5\% } \\
\text { VxG }\end{array}$ & \multicolumn{3}{|c|}{$\mathbf{0 . 1 7}$} & \\
\hline
\end{tabular}

Giza 90 (Upper Egypt cotton) showed higher total trash means compared to Delta cottons. These results are in line with El-Shafei (1995 and Khaled (2001).

The results of this analysis could be summarized as follows:

The relative importance of color measurements " Rd\% \& ${ }^{+} b$ " and both of them for Giza 90., Giza 86., and Giza 88 were subjected to analysis. To estimate the relative importance and of "Rd\%" values and the values of $\mathrm{R}^{2}, \mathrm{R}$ and regression equation of "Rd\%" are shown in Table (5). The contribution of effective variable $\mathrm{Rd} \%$ to predict total trash of Giza 90 was $\mathrm{Y}=44.48-0.639 \mathrm{Rd} \%$ with $\mathrm{R}^{2}=$ 0.91 and $R=0.95$, for Giza 86 the equation was $\mathrm{Y}=12.245-0.225 \mathrm{Rd} \%$ with $\mathrm{R}^{2}=0.6$ and $\mathrm{R}=0.77$ and for Giza 88 the equation was $\mathrm{Y}=64.62-1.023 \mathrm{RD} \%$, with $\mathrm{R}^{2}=0.96$ and $\mathrm{R}=$ 0.98 . These results are in line with Seif (2001) and Khaled (2001).

Table (5): Contribution and prediction equation of reflectance (Rd\%) for Giza 90., Giza 86 and Giza 88 cotton varieties.

\begin{tabular}{|c|c|c|c|c|}
\hline \multirow{2}{*}{ Varieties } & (Rd\%) eg & $\mathbf{R}^{\mathbf{2}}$ & $\mathbf{R}$ & $\mathbf{P}$ \\
\cline { 2 - 5 } & $\mathrm{Y}=$ Const $\pm \mathrm{Rd} \%$ & & & \\
\hline Giza 90 & $\mathrm{Y}=44.481-0.6387 \mathrm{Rd} \%$ & 0.91 & 0.95 & 0.0001 \\
\hline Giza 86 & $\mathrm{Y}=12.2456-0.2248 \mathrm{Rd} \%$ & 0.60 & 0.77 & 0.0002 \\
\hline Giza 88 & $\mathrm{Y}=64.623-1.0232 \mathrm{Rd} \%$ & 0.96 & 0.98 & 0.0001 \\
\hline
\end{tabular}

The relative importance of color measurements " $\mathrm{b}^{+"}$ for Giza 90., Giza 86., and Giza 88 to predicte total trash. $\mathrm{R}^{2}$., $\mathrm{R}$ and regression equation for $" \mathrm{~b}^{+}$" to predict total trash are shown in Table (6).

The contribuion of effective variable " $b$ " to predicte total trash of Giza 90 was $\mathrm{y}=44.48+$ $0.435{ }^{\circ} \mathrm{b}$ with $\mathrm{R}^{2}=0.91$ and $\mathrm{R}=0.95$, for Giza 
Table (6): Contribution and prediction equation of yellowness $\left({ }^{+} b\right)$ for Giza 90., Giza 86 and Giza 88. Cotton varieties.

\begin{tabular}{|c|c|c|c|c|}
\hline varieties & $\left.\mathbf{(}^{+} \mathbf{b}\right) \mathbf{e g}$ & $\mathbf{R}^{2}$ & $\mathbf{R}$ & $\mathbf{P}$ \\
\hline & $\mathrm{Y}=$ Const $\pm^{+} \mathrm{b}$ & & & \\
\hline Giza 90 & $\mathrm{Y}=44.481+0.4349^{+} \mathrm{b}$ & 0.91 & 0.95 & 0.0001 \\
\hline Giza 86 & $\mathrm{Y}=12.2456+1.2476^{+} \mathrm{b}$ & 0.60 & 0.77 & 0.0002 \\
\hline Giza 88 & $\mathrm{Y}=64.623+0.5827^{+} \mathrm{b}$ & 0.96 & 0.98 & 0.0001 \\
\hline
\end{tabular}

86 the equation was $\mathrm{y}=12.246+1.248 \mathrm{~b}^{+}$with $\mathrm{R}^{2}$ $=0.60$ and $\mathrm{R}=0.77$ and for Giza 88 the equation was $\mathrm{y}=64.62+0.583 \mathrm{~b}^{+}$with $\mathrm{R}^{2}=0.96$ and $\mathrm{R}=0.98$. These results are in line with Seif (2001) and Khaled (2001).

The most effective two variables contributing "Rd\%" and "+b" to predicted total trash. ${ }^{2}, \mathrm{R}$ and regression equation are shown in Table (7) for three Egyptian cotton varieties under study.For Giza 90 the equations was $\mathrm{Y}=44.48$ $0.638 \mathrm{Rd} \%+0.435 \mathrm{~b}^{+},\left(\mathrm{R}^{2}=0.91, \mathrm{R}=0.95\right)$, for Giza 86 the equation was $\mathrm{Y}=12.246-0.225$ $\mathrm{Rd} \%+1.248^{+} \mathrm{b}\left(\mathrm{R}^{2}=0.6, \mathrm{R}=0.7\right.$ and for Giza 88 the equation was $\mathrm{Y}=64.62-1.023 \mathrm{Rd} \%+0.583$ ${ }^{+} \mathrm{b}\left(\mathrm{R}^{2}=0.96\right.$ and $\left.\mathrm{R}=0.98\right)$.

Table (7): Contribution and prediction equation of reflectance $(\mathbf{R d} \%)$ and yellowness $\left(b^{+}\right)$for Giza 90., Giza 86 and Giza 88 cotton varieties.

\begin{tabular}{|c|c|c|c|}
\hline varieties & $\left(\mathrm{Rd}^{2} \boldsymbol{\&}^{+} \mathbf{b}\right) \mathrm{eg}$ & $\overline{\mathbf{R}^{2}}$ & $\mathbf{R}$ \\
\hline & - $\quad \mathrm{Y}=\mathrm{Const} \pm \mathrm{Rd} \% \pm{ }^{+} \mathbf{b}$ & & \\
\hline Giza 90 & $Y=44.481-0.6387 \mathrm{Rd} \%+0.4349^{+} b$ & 0.91 & $0.95 * *$ \\
\hline Giza 86 & $Y=12.2456-0.2248 \mathrm{Rd} \%+1.2476^{+} b$ & $\mathbf{0 . 6 0}$ & $0.77 * *$ \\
\hline Giza 88 & $Y=64.623-1.0232 \mathrm{Rd} \%+0.5827^{+} b$ & 0.96 & $0.98 * *$ \\
\hline
\end{tabular}

\section{REFERENCES}

Abdel-Moshsen M.R., and Al-Ashwat A.A. (1976). Cotton color a factor determining grade. Egypt. Cotton Gaz.. 67 ; 31-36.

Abdel-Moshen M.R. and Ahmed M.Sh. (1973). Effect of trash content on the Egyptian cotton grades. Egypt cotton Gaz. 61:7381.

Ahmed M.S., Kamal M.M. and Mahgoub M.A. (1984). Effect of cleaning machinery on trash content fiber properties and lint grade of some Egyptian cotton cultivars. Agric . Res. Rev. 62 (6): 277-284.

Ahmed M.S., Garawin M.S.S., Ahmed N.T. and Sheref M. V. (1987). the reliability of using instrumental measurements of trash content, Micronaire reading and color in the evaluation of cotton grade. Egypt. Cotton Gaz. 88: 40-53.

Annual Book of .ASTM Standards.(2012).(7) 2.Anthony, W.S.(1993). USDA. ARS, U.S. Cotton ginning laboratory, Stoneville,MS, USA. Paper- American Society . of Agric. Eng. (93): 1066 (24).

ASTM (2012). American society for testing and materials, A-STM (2012). standard test method for non lint content of cotton (D 2012). In: Annul book of ASTM standard ASTM International, wot cnshohockan,P.A.

Barker R. L. and Lyons D. W. (1977). Instrumented analysis of the influence of non- instrumented analysis of the influence of non- lint trash and lint color on the grading of cotton Res. J. (47):289294.

El-Shafi, M.M.I.(1995). Nep formation in cotton fiber and yarn as affected by ginning type and fiber properties .Ph.D. thesis, Fac. of Agric., El- Azhar Univ., Egypt.

Galyon M.S. and Shofner F. M. (1992). A through the mill study of neps, trash and short fiber content. Proceeding of the Beltwide cotton textile processing conference,pp. 1253- 1265.

Hegab, A.A.T. (1978). The effect of grade and processing performance on fiber and yarn properties of some Egyptian cotton varieties. Ph. D. Thesis, Fac. of Agric., Al-Azhar Univ.Egypt.

Khaled. M.M.H (2001). Foreign matter content and neps in lint cotton in relation to lint cotton grade and yarn physical properties. M.Sc. thesis, Fac. of Agric., El- Azhar Univ., Egypt .

Sallouma B.M. ( 1970). Grades analysis of long staple Egyptian cotton. Ph.D.Thesis ,Fac. of Agric., Ain Shams Univ., Egypt.

Seif M. G. (2001). Spinning performance as affected by yarn counts, twist factor and fiber properties in some Egyptian cotton varieties. Ph.D.Thesis, Fac.Agric.,Ain Shams Univ., Egypt.

Sendecor G. W.and Cochran W.G(1981). Statistical Methods $7^{\text {th }}$ Ed. Iowa State Univ.press Ames, Iowa,U.S.A. 


$$
\begin{aligned}
& \text { تقير مكونات الثوائب باستخدام جهاز ( HVI) لبعض أصناف القطن المصرى } \\
& \text { إسامه دسوقى محمد نور } \\
& \text { معهد بحوث القطن - مركز البحوث الزراعية ـ الجيزة- مصر }
\end{aligned}
$$

يقدم البحث تقدير الثو ائب فى بالة القطن بطريقة سريعة ، و و يمكن الإعتماد عليها عن طريق حسـاب عاملين هامين

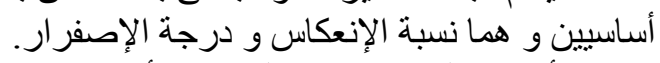

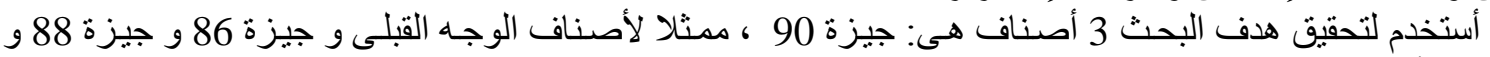

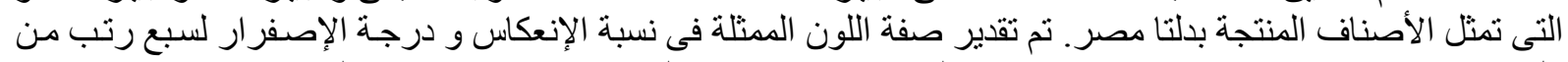

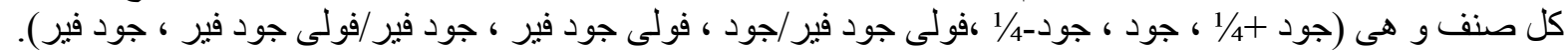

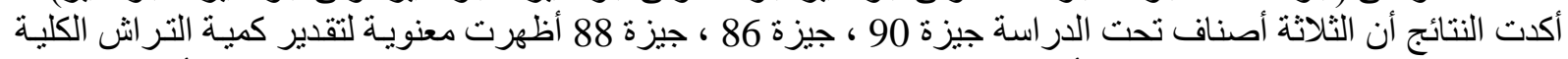

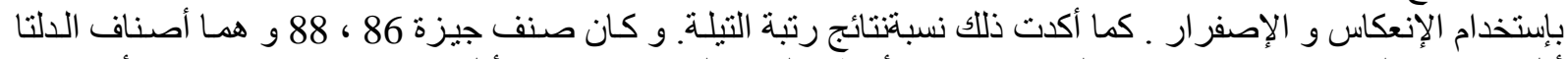

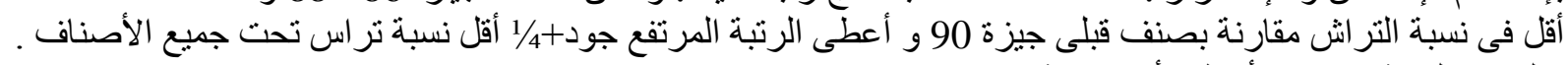

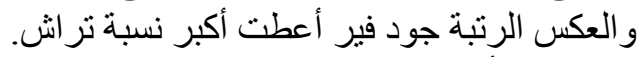

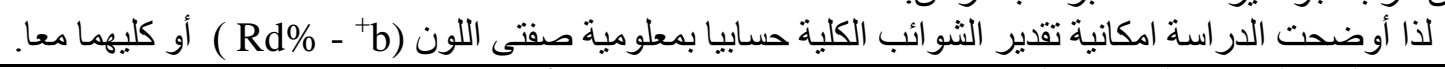

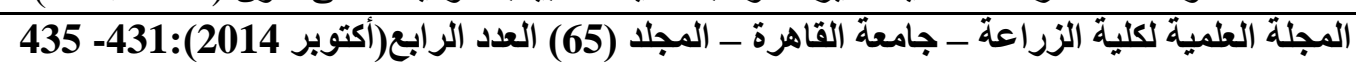

